\title{
BETWEEN CONTINENTS: AGATHA CHRISTIE'S TRANSLATIONS AS INTERCULTURAL MEDIATORS
}

\author{
Vanessa Lopes Lourenço Hanes* \\ Universidade Federal Fluminense
}

\begin{abstract}
Agatha Christie's trajectory in the Brazilian literary polysystem serves as an illustration of how translated literature can demonstrate the complexity of intercultural mediation, with books and authors acting as agents that interconnect several cultures in a far-reaching and even unexpected web of relations. Three apparently simple aspects of the interaction in this case are introduced to the reader (the importation of Agatha Christie from England to Brazil, her exportation from Brazil to Portugal and, finally, the nuancing of her presence within Brazilian Portuguese language and culture). Specific examples of these aspects show how translated literature can provide insight into the dynamic interfaces between and within different cultures.
\end{abstract}

Keywords: Agatha Christie. Intercultural Mediators. Portuguese Language. Translated Literature.

* Vanessa Lopes Lourenço Hanes: PhD (2015) and MA (2011) in Translation Studies (2015) from the Federal University of Santa Catarina (UFSC), Brasil. BA in Social Work (2004) from the Londrina State University (UEL), Brazil. She is an Adjunct Professor of English at the Fluminense Federal Univeristy (UFF), Brazil. Niterói, Rio de Janeiro, Brazil. E-mail:vanessahanes@gmail.com 


\title{
ENTRE CONTINENTES: AS TRADUÇÕES DE AGATHA CHRISTIE COMO MEDIADORES INTERCULTURAIS
}

\begin{abstract}
Resumo: A trajetória de Agatha Christie no polissistema literário brasileiro é usada para ilustrar como a literatura traduzida pode demonstrar a complexidade da mediação intercultural, com livros e autores fazendo o papel de agentes que interconectam várias culturas em uma rede de relações complexa e até mesmo inesperada. Três pontos de vista aparentemente simples são apresentados ao leitor (Agatha Christie importada da Inglaterra para o Brasil, exportada do Brasil para Portugal e, finalmente, nuances da presença dela dentro da língua portuguesa e da cultura brasileiras). Exemplos específicos desses aspectos mostram como a literatura traduzida pode facilitar a compreensão das interfaces dinâmicas entre diferentes culturas e dentro das mesmas.
\end{abstract}

Palavras-chave: Agatha Christie. Mediadores Interculturais. Língua Portuguesa. Literatura Traduzida.

\section{Introduction: Agatha Christie's works and their inter- mediary role in world literature}

Since the end of the twentieth century and due to the globalization phenomenon, (Comparative) Literary Studies seem to have realized that Goethe's concept of Weltiteratur ${ }^{1}$ deserves to be rediscovered, and that this challenge cannot be successfully addressed without other (re)discoveries such as translation and (de)colonization. There is no need to stress that the contemporary world looks much bigger than it did for eighteenth-century Europeans. Thus, our research tasks are also becoming more and more complex.

\footnotetext{
${ }^{1}$ The concept of Weltliteratur was originally used by Johann Wolfgang von Goethe in several of his essays in the nineteenth century to describe the international circulation and reception of literary works in Europe, and is used in this article in English ("world literature") to refer to the circulation of literary works into the wider world beyond their country of origin. The concepts of "literary classics" and "Great Books" are seen as closely related, generally referring to those books considered the world's literary masterpieces. For more information on Goethe's concept of Weltliteratur, see Eckermann (1930).
} 
Translated literature has often been approached as an interaction between individual writers, languages and countries. However, there is a good chance that much more intricate intercontinental relations are involved in the translation and distribution of the Great Books. And that is what Agatha Christie's trajectory in Brazil can teach us. The very idea that the Brazilian literary market could class Agatha Christie among the Great Books, as will be demonstrated from several examples, certainly comes as a surprise. ${ }^{2}$ But while her works were travelling to Latin America through the canonized channels of world literature, at the very moment when the young nations in that continent were establishing their literary knowledge and values, detective stories almost inevitably ended up taking a place on the bookshelves next to much more prestigious writers such as Shakespeare or Plato. Even-Zohar points out that

The most obvious case of import seem to be that of bringing in goods to fill in certain functions which are absent in the target. That is, import may occur whenever the goods that are imported are not available on the home market and a willingness to consume them is somehow aroused among the members of the targeted group. $(1997,359)$

The underlying basis for the present text is that intellectual goods as well as other products depend on multiple channels: neither Shakespeare nor Christie were discovered in English only, and their presence in Portuguese-speaking cultures was (and still is) partially mediated by other cultures, at the same time that those translations become agents of intercultural mediation. The data to be introduced here should illustrate how Agatha Christie

\footnotetext{
${ }^{2}$ According to the Index Translationum, Agatha Christie has been translated more often than any other author (information available at: http://www.unesco.org/xtrans/bsstatexp. aspx? crit $1 \mathrm{~L}=5 \& \mathrm{nTyp}=\min \& \operatorname{topN}=50$ ). Nonetheless, being a popular author does not automatically make her writings into classics. That is why her inclusion side by side in a collection with authors such as Plato (to be examined later on) came as a surprise.
} 
is indeed part of world literature, showing that her translations are symptomatic cases in Portuguese-speaking societies, as they probably are in other countries, ${ }^{3}$ while at the same time showing trends that may also apply to other authors in Brazil and Portugal. ${ }^{4}$

The insights to be shared with the reader are part of the findings of a $\mathrm{PhD}$ dissertation on the translation of oral discourse in written format in Brazil, whose ultimate goal was a better understanding of Brazilian cultural dynamics by using translation studies as a starting point. Agatha Christie's translations were chosen as a case study because they contain a world of possibilities. Between the 1930s, when Christie was first translated in Brazil, and today, when she is still abundantly published and republished, translated and retranslated, the global situation has changed immensely. And this synchronically and diachronically immense corpus furnishes much data.

While analyzing the translations of Agatha Christie's works in Brazil, it became clear that the trajectory of this author was not just about two countries, or just about the source culture and the target culture. Agatha Christie cannot be seen as a simple bilateral story between Brazil and England or even, if we just consider the target texts, between Brazil and Portugal. Hopefully this article will demonstrate how Christie's translations can serve as examples of intercultural mediators in a complex network of relations.

\footnotetext{
${ }^{3}$ Regarding other countries, Leroi's 1978 study on Christie's French translations serves to illustrate the relevance of Christie's translations in that language as a case in point at a micro level, whereas Clem Robyns (1994) demonstrates the importance of Christie's French translations, along with that of other detective fiction writers, at a macro/editorial level.

${ }^{4}$ Another interesting symptomatic case in Brazil (among many other possibilities) would be that of Edgar Allan Poe, who was vastly translated into Portuguese utilizing radically different approaches. A brief example: Gonçalves (2006) analyzes a translation of Poe made by Clarice Lispector and points out that the acclaimed Brazilian author retells Poe's text using her own writing style.
} 


\section{Europe vs. Latin America: three instances of Agatha Christie's works as intercultural mediators}

In order to illustrate the above-mentioned network, three different sub-cases will be introduced and exemplified. These show that not even apparently uni- or bilateral issues are straightforward where Agatha Christie is involved (and the same might be expected for other authors); the complexity of this multi-faceted and even unlikely network of relations becomes more obvious as these individual sub-cases are unraveled. Although the information here is merely the tip of an immense iceberg of possibilities, it should at least stimulate dialogue about the world's "transland".

\subsection{From England to Brazil: the obvious first step}

When speaking of translations, the obvious and most strict definition that comes to mind is that of a source text being transferred into a target text. According to Munday (2012), the traditional focus of translation studies has been on aspects of the transference of a text between two different verbal sign systems. Consequently, in such a perspective, only two cultures seem to play a role in the translation process: the source and the target cultures.

The problem with this approach is that nothing is really that simple, much less so when considering a prolific and ubiquitous author like Christie. While looking at the supposedly direct, linear and unidirectional relation between the source and the target cultures, many other actors and circumstances surface, demonstrating the multi-determination of this exchange. Translation in Brazil, as in any other culture, "does not happen in a vacuum, but in a continuum; it is not an isolated act, it is part of an ongoing process of intercultural transfer" (Bassnett, Trivedi, 2).

As far as could be observed, there was no detective fiction in Brazil before the introduction of Agatha Christie and her peers in 
the 1930 s. ${ }^{5}$ This entirely new genre apparently sprang fully formed from England to Brazil at that one specific historical moment. But this process was far from a simple unilateral movement.

The first example, on a macro-level, ${ }^{6}$ has to do with the first book collection to feature Christie in Brazil. Translation of her works began as part of a new collection published by the Livraria do Globo (now known as Editora Globo) called Coleção Amarela (i.e., Yellow Collection).

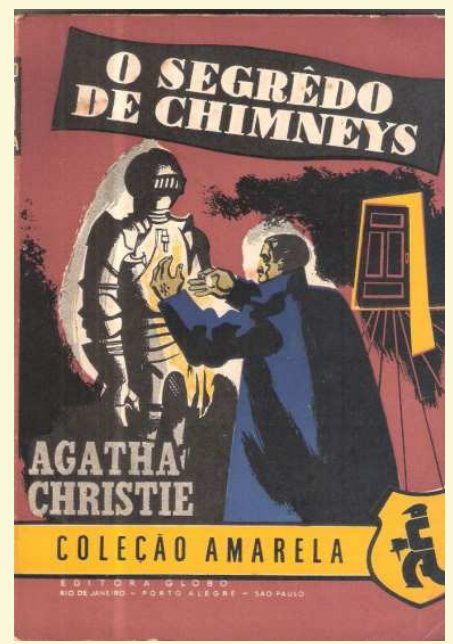

Figure 1. Cover of one title (The Secret of Chimneys) from the Coleção Amarela

At first sight, the name of this collection seemed odd. Why yellow, and not red or some other color? And why choose a color for the name of a book collection? Some informed speculation,

\footnotetext{
${ }_{5}^{5}$ The only publication found dating from before the 1930s (Christie's first translation was released in 1933) of any detective-like stories translated into Brazilian Portuguese was that of an edition of short stories authored by Edgar Allan Poe, produced by H. Garnier LivreiroEditor between 1901 and 1903.

6 The terms "macro" and "micro" level are used according to the terminology applied by Lambert and van Gorp (1985) in their well-known guidelines to describe translations.
} 
however, has uncovered a clue regarding this mystery. And the answer has nothing to do directly with either the source or target culture; in fact, these books were not simply transmitted from England to Brazil; they were filtered through a circuitous cultural migratory process that left the imprint of other nations, as the following example illustrates:

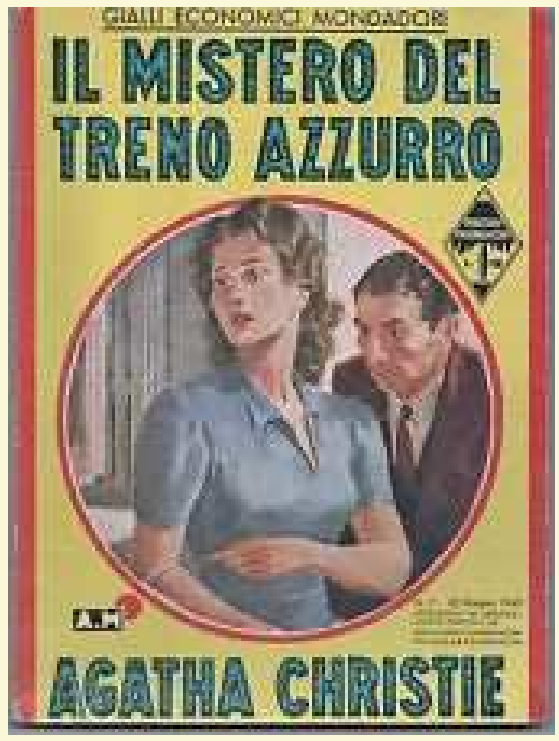

Figure 2. Cover from a title in the Italian collection Gialli Economici Mondadori

In Italy, both historically and today, detective stories are generally published with yellow covers and are known as gialli [yellows]. ${ }^{7}$ Such books have been published in this format since the 1920s, a decade before the Brazilian Coleção Amarela was created. Of course Christie's books have also been published

\footnotetext{
${ }^{7}$ Weller (2012) writes about Mondadori's introduction of its long series of gialli in the $1920 \mathrm{~s}$, and this publisher's website (available at: http://www.mondadoristore.it/migliori-librigialli-thriller-2015/\#.VtcyNVsrIed) provides a list of the best gialli of 2015, demonstrating the current usage of the term.
} 
with yellow covers in other countries, but the strength of this connection between the yellow covers and detective novels in Italy is striking.

The second example, this time on a micro-level, further demonstrates the influence of other nations in the Brazilian reinvention of Agatha Christie. This example was obtained from the oldest Agatha Christie translation found for sale on the Brazilian used book market: ${ }^{8}$ a 1933 translation of The Murder of Roger Ackroyd, entitled O Assassinato de Roger Ackroyd. It was translated by Heitor Berutti for Livraria do Globo. Berutti chose to translate most of the proper names used by Christie. Even Roger was translated as Rogério (although curiously left untranslated in the title). However, one of his translation choices was strangely telling: "James", one of the main characters of this story, was translated in Berutti's Brazilian version not as "Tiago", the normal and expected translation in Portuguese, but as Jaques. However, Jaques is by no means a common name in Brazil. It is, of course, a derivation of the French name Jacques, which indicates a certain level of French cultural influence in this translation.

Two explanations come to mind when considering this odd choice. The first and most obvious is the possibility that this work was an indirect translation. This would hardly be surprising, since Brazilian literary tradition has historically relied quite heavily on French mores, with indirect translations via French as the norm for quite some time in Brazil. Amorim (2000) points out that at the beginning of the 1900s, books were imported mainly from France; French prevailed as a literary lingua franca in the country, being used as an intermediary for translations.

Nevertheless, an irreconcilable difficulty appears to frustrate such a hypothesis about Berutti's choice: in a French translation from 1927 released by Librairie des Champs-Élysées (apparently the first to publish Christie in French) the name of the character

${ }^{8}$ Libraries were also consulted, but this was the oldest physical copy of an Agatha Christie translation that could be found for analysis. 
was maintained as "James", as in the English original. This appears to have been the main publishing house to release Agatha Christie on the French book market and, thus, the most probable French version to have reached Brazil and Berutti. And yet it contained no translated names. There is a good chance that two different French translations of the same book would not have been released at the same time. So, if Berutti was not modelling his translation after a/ the mainstream French version, why insert such a fanciful name?

This leads us inevitably to the second possible explanation for this unusual micro-level element: he was producing what might be called a "pseudo-indirect translation", i.e. making his translation appear to have been derived from the French, giving it "French airs", since at the time French literature still played a prestigious role in Brazil (Amorim 2000, Wyler 2003). The text produced by Christie, an English writer, may have been made to look a little more French to please a historically Francophile audience. Although no other examples have been observed in Christie translations to confirm this as a trend, such a motivation should not be ignored in this case.

These two examples of the interference of other cultural traditions begin to demonstrate why a simple binary understanding of translation is insufficient to reveal the dynamics behind Christie's introduction into the Brazilian cultural system.

\subsection{From Brazil to Portugal: a less likely case}

Another relationship in this network is less commonly analyzed yet quite complex: the literary exchange between Brazil and Portugal. Interestingly, in this case Brazil was the source of Christie translations for the former colonizer. Sampaio (2007) documents that, contrary to expectations, Brazil was actually exporting detective story translations to Portugal in the 1930s and 1940s. However, this counterintuitive twist in the relations of power, i.e. between a colony replete with social/educational problems exporting (of all things) literature to its former colonizer, is perhaps better explained 
by some examples presented below. Nevertheless, there is still much more to this already surprising story.

The first example is again from the Brazilian version of The Murder of Roger Ackroyd mentioned in the previous section. This same translation by Berutti was sold to the Portuguese publishing house Livros do Brasil and published in Portugal in a popular and, later, classic book collection called Colecção Vampiro, with a few adaptations to European Portuguese. The language use in the Brazilian and Portuguese versions of this translation is revealing: the register in this translation is higher than both Christie's English original and the common Brazilian usage that would adequately express Christie's generally informal tone. Moreover, Berutti's translation happened to be much closer to everyday European Portuguese usage even before any adaptations were made to it.

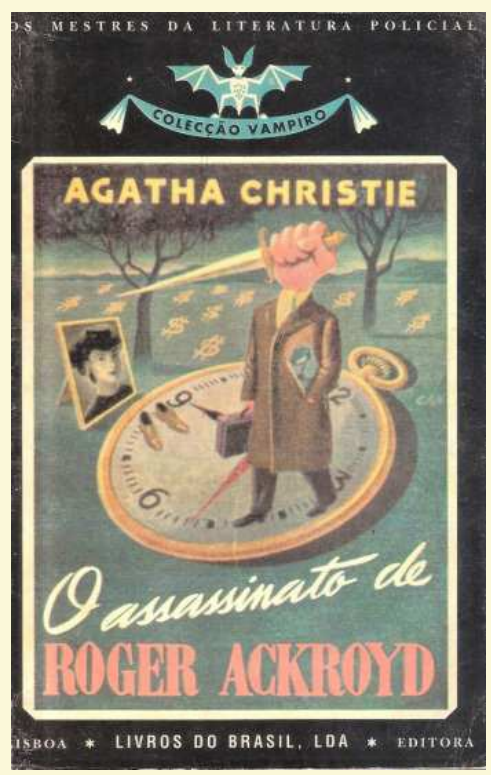

Figure 3. Cover of $O$ Assassinato de Roger Ackroyd [The Murder of Roger Ackroyd] published in the Colecção Vampiro 
Although John Milton (2002) previously demonstrated that there has been a systematic elevation of register in Brazilian translations of the Great Books, such as the works of Charles Dickens, the same can also be applied to popular literature, since the same trend is quite apparent here in the case of Agatha Christie. The characteristics indicative of high register found throughout Berutti's translation, particularly those involved in direct speech, are more common in the oral discourse of European Portuguese. Structures that would seem bookish to a Brazilian reader would be absolutely normal to a Portuguese reader, even though the translation was ostensibly created for a Brazilian audience.

One such characteristic would be the use of ênclise. ${ }^{9}$ Brazilian speech is heavily dependent on próclise (see Machado 2006, Morais \& Ribeiro 2004), yet, when oral discourse is represented in Christie translations, ênclise is adopted. Of course one could argue that in 1933 (when Berutti undertook this translation) usage was much different, and that ênclise would have been perfectly acceptable in those more formal times. However, the idea that Brazilian translational norms have always been tied to common speech is confounded when comparing Berutti's work with a 2010 retranslation of the same title by Renato Rezende. This new translation inexplicably includes many uses of ênclise, which at this point must clearly be considered extinct and obsolete in Brazilian speech. Rezende's register indicates, rather than an expected trend of greater informality - especially for pulp fiction such as Christie's -, an inherited norm of artificially high register strong enough to prevail over the very speech the translator uses every day.

Enclise has not appeared in everyday discourse (including the media) for so long that schoolchildren have a difficult time learning how to use it in writing, i.e. it is an alien feature of the language (see Machado 2006). Nevertheless, technically speaking, it is still considered grammatically correct; so, apparently on no other basis

\footnotetext{
${ }^{9}$ Ênclise: hyphenated construction comprised of a verb form followed by an oblique pronoun. Example: Disse-me. Próclise: construction comprised of an oblique pronoun followed by a verb form. Example: Me disse.
} 
than this (when not taking inherited norms into consideration), it is abundantly used in written format even to represent informal conversations in direct speech such as those found in Agatha Christie. There is fierce ongoing debate in Brazil regarding this practice, and authors such as Marcos Bagno (2000, 2007, 2010 and 2011) challenge the current system. But the ultimate truth exposed by this ongoing language policy is that, to a certain extent, the former colonizer still rules. ${ }^{10}$ One could thus claim that the European Portuguese linguistic norm maintains a lingering grasp on Brazilian translators and, to a certain extent through them, on Brazilian culture.

Thus, the fact that Brazil could export translations to Portugal does not show, as might be hastily deduced, that the tables had finally turned between colony and colonizer but, rather, that a convenient similarity prevailed in the written language that was detached from actual Brazilian usage.

However, even though the Brazilian case has its own particularities, this elevation of register in Agatha Christie translations is not unique to Brazil. Studies have indicated the presence of the same phenomenon in other languages and cultures: Leroi (1978) observed a systematic elevation of the register in French Agatha Christie translations and Storm (2016) found traces of higher register both in Dutch and in German translations of Christie. This further demonstrates how Christie's works serve as an intercultural marker: cultures without a clearly traceable history of literary interaction still present common approaches to translating her. Thus Christie serves as a starting point for establishing unlikely connections between cultures and communities as distinct as Brazil and the Netherlands.

Berutti's translation of The Murder of Roger Ackroyd can be used to add one more layer to the improbable connections that can be established in the circulation of Christie's works. A subtle irony can

10 For more information on the language policy found in different translations of Agatha Christie in Brazil, see Hanes (2015) 
be seen in the European Portuguese version of Berutti's treatment of the name James: Jaques was left untouched, except to correct it to the proper French spelling, i.e. Jaques became Jacques. This tiny correction speaks volumes: it shows, as previously stated, that a most likely direct translation from English into Brazilian Portuguese was made, apparently, into a pseudo-indirect translation due to a question of status. But it also shows that the same status given to the French language in Brazil was also true in Portugal, since the name was not only kept but care was taken to correct its spelling in the European version. It could not be determined whether the Portuguese text revisers had access to the text in English to verify that the original name was James and not Jacques. Nevertheless, the fact that French language and French culture were valued in Portugal is demonstrated by the fact that indirect translations via French were openly declared in the Colecção Vampiro (which makes one wonder if saying "translated from French" was automatically seen as a synonym of high quality). The open mention of the indirect translation of a text can be observed, for example, in a 1948 Portuguese edition of Ten Little Niggers entitled (semi-translated here by the author) "Convite para a Morte (translation from the French by Batista de Carvalho)".

\subsection{Glimpses of an even more complex web}

We seem, in a way, to be developing a top-down analysis of Agatha Christie's role of connecting Brazil to other cultures; first in the relationship between English and Brazilian literature, then within intercontinental Portuguese (and the many agents involved in its interchange). The focus will now be further reduced to Agatha Christie specifically within Brazilian Portuguese and Brazilian culture. Nevertheless, despite narrowing the object of study, its level of complexity is hardly reduced, which is due principally to the fact that, in many respects, Agatha Christie is treated as canonized literature within the Brazilian literary and cultural polysystems. There is abundant evidence of this fact, as will be briefly demonstrated below. 
An important sign of Agatha Christie's canonization in Brazil is her gradual inclusion in different book series of varying formats and styles over time. According to a detailed study carried out by Amorim (2000) about the early history of Editora Globo, Agatha Christie was first published in Brazil in a book series (the previously mentioned Coleção Amarela) with other authors of detective fiction such as Ellery Queen, Edgar Wallace and George Simenon. Although these stories were originally published in the cheapest possible style, as newsprint pocket books, once other Brazilian publishing houses became aware of the queen of crime's great success in the market, they began to produce edited Christie collections. Many versions of the Coleção Agatha Christie came into existence, released by different publishers: Editora Globo, Editora Record and Editora Nova Fronteira invested heavily in the production of new editions of Christie's translations in Brazil. The quality of the physical copies also improved considerably: high-quality bleached paper was later used, and even the standard pocket book format was abandoned altogether for some time. Both Record and Nova Fronteira also published hardback versions of their Agatha Christie collections.

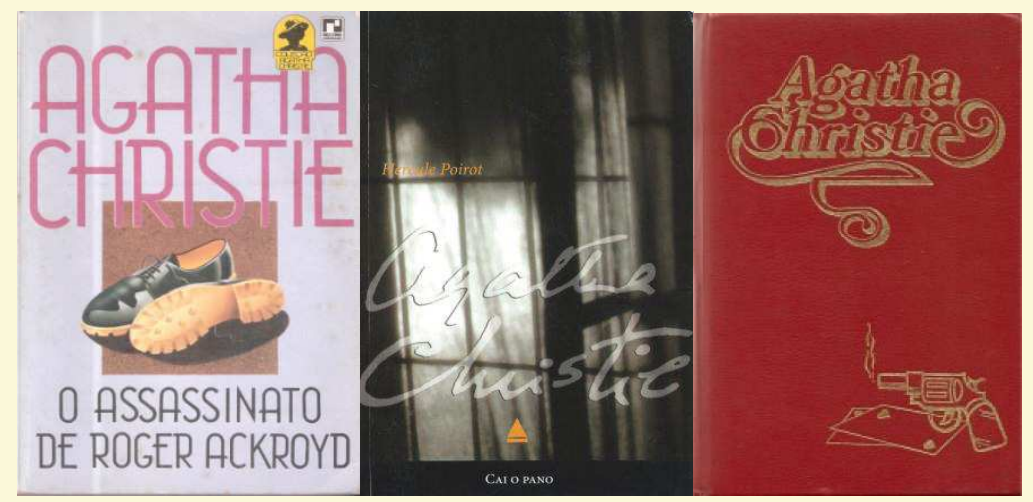

Figure 4. Covers of some of the different Agatha Christie book collections published in Brazil 
Christie's most recent inclusion in a book series, however, serves as the ultimate expression of her appraisal in Brazil. In 2011, for the first time, Christie was published in a new book series released jointly by Editora Nova Fronteira and Livraria Saraiva (perhaps the most successful bookstore chain in Brazil) called the Coleção Saraiva de Bolso. And in this new book series Christie was not only placed on a par with Brazilian authors such as José de Alencar (1829-1877) and Machado de Assis (1839-1908), but with the zenith of world luminaries such as Plato, Machiavelli, Shakespeare and a limited number of others. Even the cover of each book is personalized with a modernesque semi-cubist caricature of its author; authors with more than one work in the series (as is Christie's case) are graced with a different caricature for each title. This is a clear demonstration that Agatha Christie has reached the pinnacle of the Brazilian literary canon, at least according to popular commercial publishers.

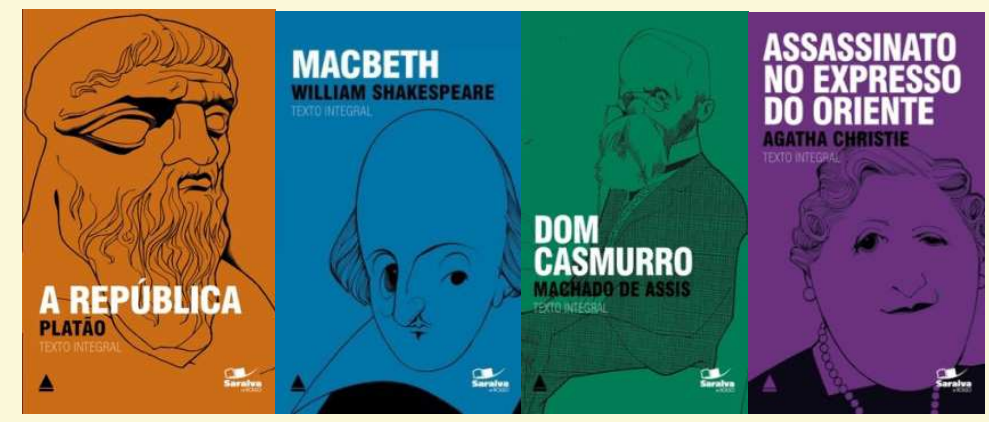

Figure 5. Covers from the Coleção Saraiva de Bolso

Christie is also being treated as canon in Brazilian literary (i.e., academic) publishing: at least since 2000, Editora Globo has been publishing reading supplements in every edition it releases of Christie's books. Such supplements are developed by language teachers, particularly for use in high school literature classes. The activities run the gamut from reading comprehension to essay 
writing, and also include recommended reading and questions for reflection. Since, according to Fowler (1979), education is one of the means of reinforcing canonization in a culture, Christie is thus being treated as sensu stricto literary canon, not only by publishers, but by the education system as well.

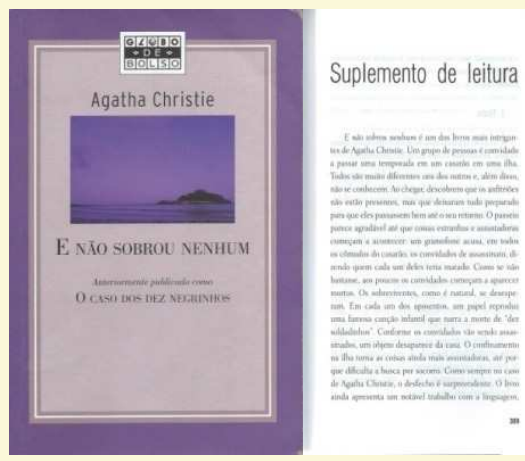

Figure 6. Cover of a recent Brazilian Portuguese translation of And Then There Were None with the beginning of the accompanying nine-page Reading Supplement (Editora Globo 2008).

However, other signs point to Christie's continued exclusion from this same class. One example of this would be that her presence in traditional Brazilian encyclopedias such as Barsa is very restricted (only one entry was found for her name vs. eight for Machado de Assis and seven for Shakespeare). ${ }^{11}$ Canonized authors are extensively mentioned in reference books, which demonstrates that Christie is not yet fully on a level with such names.

Considering Christie's translations from a micro-level point of view, indications that she has been handled as canonized literature can be found from the beginning of her trajectory in Brazil. Wordlevel instances within specific translations, such as those of Leonel Vallandro, bear this out. Vallandro's translation of $O$ Assassinato de Roger Ackroyd serves as a convenient example. Released in 1951,

${ }^{11}$ The Enciclopédia Barsa online version (http://brasil.planetasaber.com/default.asp). 
it is characterized by Portuguese usage consistent with that found in Brazilian literary classics, such as Machado de Assis, whose career began almost a century earlier. As a result, the Brazilian translation is produced in a much higher register than the English source text. The following example of direct speech is typical:

- Ralph e eu nos separamos pouco antes das nove e três quartos. Êle não se aproximou da casa, disso tenho plena certeza. E não tencionava fazê-lo; tudo teria feito naquela noite, menos enfrentar o padrasto. (236) (emphasis added) "Ralph and I parted just before a quarter to ten. He never went near the house, I am sure of that. He had no intention of doing so. The last thing on earth he wanted was to face his stepfather." (282)

In this passage, the register is inflated when telling time, in the ênclise structure and in vocabulary such as tencionava [had intention]. Additionally, the inversion of common syntax in the italicized phrase imparts quite a poetic air compared to Christie's matter-of-fact delivery. The character speaking here is Ursula, who, although not completely uneducated, should be incapable of producing the florid Portuguese discourse attributed to her. Moreover, specific erudite vocabulary found repeatedly in Assis' masterpieces (from more than fifty years earlier), such as alvitre [proposal], are also used repeatedly by Vallandro, although there is little indication they were still part of everyday Brazilian discourse in the 1950s. These examples should suffice to demonstrate, on a discursive level, how Christie has been translated into Brazilian Portuguese as if her oeuvre was on the highest canonized literary level.

Given the examples mentioned above, it would be naive to dismiss these strong indications of Christie's canonization in Brazil. So now we may ask: and what does this have to do with intercultural mediation? One of the definitions of "to mediate" 
given by the Merriam-Webster is "to reconcile differences". And the introduction of Agatha Christie's writings in Brazil seems to be a valid example of exactly that: a practical reconciliation of several different elements from different cultures. It does not seem an exaggeration to say that Christie was reinvented for her incorporation into the Brazilian literary polysystem. While her writings changed the literary - and even the cultural - milieu by spearheading a new genre, her books underwent a gradual metamorphosis within Brazilian culture. This included conformity to entrenched structural elements such as register elevation that (eventually) contributed to transforming disposable pulp fiction into prestigious canonized literature.

\section{In closing: what did Agatha Christie have to teach us about intercontinental relations?}

The evidence presented in this article indicates, first of all, that the undeniable success of Christie's detective stories is hardly just a question of a binary source-target exchange. The multilateral nature of Christie's trajectory may be applicable in a more generalized way: it could be symptomatic of a much larger phenomenon at work in many different authors within Brazilian culture, if not other cultures as well, since elevated register seems to be widespread in translation. Translator diction has played an important (and often overlooked) part in this complex web, first of all in light of the exaggerated written-oral dichotomy in Brazilian communication, which differentiates it to a certain degree from that of its colonizer. Christie translations in Portuguese demonstrate hesitations, fluctuations and - often implicit - conflicts. Admittedly or not, Brazilian (and Portuguese) translators and publishing houses have used Christie to mark their position regarding the standardization of the Portuguese language over the course of nearly a century. And the type of language used to translate Christie has facilitated her canonization, which is itself indicative of much in the Brazilian 
literary system. Nevertheless, both the trajectory and the means by which this canonization has occurred are also important for Translation Studies. Finally, however, there is more at stake here than simply the question of language. The French and, surprisingly, Italian influence observed in the Brazilian Agatha Christie cosmos are suggestive of the many social, political and economic factors involved in the transfer and reshaping of cultural goods and cultural identities and indicate paths for richer levels of discussion.

\section{References}

Amorim. Sonia Maria de. Em Busca de um Tempo Perdido: Edição de Literatura Traduzida pela Editora Globo (1930-1950). São Paulo: EDUSP, 2000.

Bagno, Marcos. Dramática da Língua Portuguesa: Tradição Gramatical, Mídia e Exclusão Social. São Paulo: Edições Loyola, 2000.

- Nada na Língua é Por Acaso: Por Uma Pedagogia da Variação Linguística. São Paulo: Parábola Editorial, 2007.

. A Norma Oculta: Língua e Poder na Sociedade Brasileira. São Paulo: Parábola Editorial, 2010. . A Língua de Eulália. São Paulo: Contexto, 2011.

Bassnett, Susan and Trivedi, Harish. (Eds.) "Of Colonies, Cannibals and Vernaculars". Post-colonial Translation: theory and Practice. London/New York: Routledge (2000): 1-18.

Christie, Agatha. O Assassinato de Roger Ackroyd. Trans. Heitor Berutti. Porto Alegre: Livraria do Globo, 1933. 
. O Assassinato de Roger Ackroyd. Trans. Leonel Vallandro.Porto Alegre: Editora Globo, 1972.

. Le Meurtre de Roger Ackroyd. Trans. Miriam Dou-Desportes. Paris: Librairie dês Camps-Élysées, 1969.

. O Assassinato de Roger Ackroyd. Trans. Renato Rezende. São Paulo: Editora Globo, 2010.

. Convite para a Morte. Trans. Batista de Carvalho. Lisboa: Livros do Brasil, 1948.

. The Murder of Roger Ackroyd. New York: Dodd, Mead \& Company, 1926.

Eckermann, Johann Peter. Conversations with Goethe. Trans. John Oxenford. Dent/Nova York: E. P. Dutton, 1930.

Even-Zohar, Itamar. "The making of culture repertoire and the role of transfer" TARGET International Journal of Translation Studies 9.2 (1997): 355-363.

Fowler, Alastair. "Genre and the Literary Canon." New Literary History 11.1 (Anniversary Issue: II, 1979): 97-119. Available at: <http://www.unife. it/letterefilosofia/lm.lingue/insegnamenti/letteratura-inglese-ii-lm-lingue/ programma-bibliografia-calendario-lezioni-modalita-desame-e-materialedidattico-anno-accademico-2012-2013/Alastair \% 20Fowler-\% 20Genre \% 20 and\%20the\%20Literary\%20Canon-\%201979.pdf > . Access: Aug 162014.

Gonçalves, Fabiano Bruno. Tradução, Interpretação e Recepção Literária: Manifestações de Edgar Alan Poe no Brasil. Dissertação. Porto Alegre: UFRGS, 2006.

Hanes, Vanessa Lopes Lourenço. The Language of Translation in Brazil: Written Representations of Oral Discourse in Agatha Christie. Tese. Florianópolis: UFSC, 2015. 
Index Translationum. Available at: < http://www.unesco.org/xtrans/bsstatexp.as px?crit $1 \mathrm{~L}=5 \& \mathrm{nTyp}=\min \& t o p N=50>$. Access: Feb 29, 2016.

Lambert, José and Gorp, Hendrik van. "On Describing Translations." The Manipulation of Literature. Studies in Literary Translation. Ed. Theo Hermans. London \& Sidney: Croom Helm (1985): 42-53.

Leroi, C. Agatha Christie en Français ou la Traduction du Roman Policier. Dissertation, Leuven: Katholieke Universiteit Leuven, 1978.

Machado, A. C. M. O Uso e a Ordem dos Cliticos na Escrita de Estudantes da Cidade do Rio de Janeiro. Dissertação. Rio de Janeiro: UFRJ, 2006.

Merriam-Webster Online Dictionary. Available at: < http://www.merriamwebster.com/dictionary/mediate >. Access: Feb 18, 2015.

Milton, John. O Clube do Livro e a Tradução. Bauru: EDUSC, 2002.

Mondadori Store. I 10 Libri Gialli e Thriller Più Belli del 2015. Available at: < http://www.mondadoristore.it/migliori-libri-gialli-thriller-2015/\#. VtcyNVsrIed > . Access: March 2, 2016.

Morais, M. A. T. and Ribeiro, I. "Colocação dos Clíticos no Português Europeu e Brasileiro." Revista Linha D'Água 17 (2004): 22-41. Available at <http:// www.revistas.fflch.usp.br/linhadagua/article/view/158> . Access: July 102014.

Munday, J. Introducing Translation Studies: Theories and Applications. $3^{\text {rd }}$ Ed. Routledge: New York, 2012.

Robyns, Clem. "Translation and discursive identity." Poetics today 15.3 (1994): 405-428.

Sampaio, Maria de. Lourdes R. M. História Crítica do Género Policial em Portugal (1870-1970): transfusões e transferências. Tese. Porto: Universidade do Porto 1.0 (2007). 
Storm, Marjolijn. Agatha Christie's The Mysterious Affair at Styles in German and Dutch Translation: The Remarkable Case of the Six Poirots. Leiden/Boston: Brill Rodopi, 2016.

Weller, Philip. "Italian Crime Fiction: A Barbarian Perspective." Linguce \&-Rivista di lingue e culture moderne 11.1\&2 (2012): 119-132.

Wyler, Lia. Línguas, Poetas e Bacharéis: Uma Crônica da Tradução no Brasil. Rio de Janeiro: Rocco, 2003.

Recebido em: 17/06/2016 Aceito em: 23/09/2016 Publicado em janeiro de 2017 